\author{
Professor Daniela SERBAN, PhD \\ E-mail: danielaserban2011@gmail.com \\ Associate Professor Corina PELAU, PhD \\ E-mail: corina.pelau@ fabiz.ase.ro \\ Associate Professor Violeta Mihaela DINCA PhD \\ E-mail: violeta.dinca@fabiz.ase.ro
}

\title{
PANEL DATA ANALYSIS FOR MEASURING THE IMPACT OF E-SKILLS ON THE ECOLOGICAL BEHAVIOR OF INDIVIDUALS
}

\begin{abstract}
The decision of individuals to support and get involved in ecological and recycling oriented activities relies upon a set of factors which are associated to the level of development of the country of residence and also to personal characteristics. Many studies have emphasized the importance of education as an influencer of people's ecological behaviour. Education represents a broad term, but in the era of the new knowledge economy, a particular significance is given to the skills related to the information and communication technologies and digitalization, covered by the term of "e-skills". The main objective of this paper is to display the outcomes of a research about the ecological and recycling-centered behaviour of European citizens, more precisely to investigate the correlation between the computer and internet-skills and the proenvironmental behavior. The results of a panel data analysis show that the recycling rate in an economy is mostly influenced by the percentage of people having an average number of computer and internet skills (3-4 skills). The percentage of people with low computer and internet skills (1-2 skills) have in some situations an influence on the recycling rate. The same research shows that the percentage of high qualified computer and internet users (5-6 skills) is not correlated with the pro-environmental behaviour.

Keywords: pro-environmental behaviour, e-skills, education, recycling oriented behaviour, panel data analysis, regression, coefficients.
\end{abstract}

JEL Classification: M10, Q53

\section{Introduction}

One of the main objectives of the sustainable development of an economy is frequently associated with issues like waste management and recycling. Waste recycling (a strategy of waste management) embodies an option for the re-use of recoverable parts of resources, particularly in this era of wide consumerism. An efficient waste recycling plan generates many advantages, such as environmental benefits, sanitary solutions, social, economic and educational issues. By applying

DOI: $10.24818 / 18423264 / 53.1 .19 .04$ 
an efficient waste recycling, there is diminished the utilization of raw materials, the quantity of waste transported to landfills or incinerators and it can spawn job possibilities and revenues, in developing countries (Conke, 2018).

Given the fact that the EU will adopt a new 2030 target (of 65\%) in conformity with the new circular economy package adopted by the European Commission, EU member states are well represented in high performers of recycling. It is therefore important to shine a spotlight on the measures taken within these states to accomplish favorable achievements on recycling. Investigating these features carries two directions: setting up the performance of recycling activities and determining the factors that have an impact on the respective performance. It is important to take into consideration all these aspects on the background of the new knowledge economy characterized by digitalization and ICT development.

In the first part of the paper, the focus is put on the literature review, with accent on the weight of the recycling process in the circular economy and on other researches showing the relation between various types of skills (anchored within the education process of the new knowledge, digital economy) and the recycling rate. The objective of this paper is analyze the relation between the recycling rate of municipal waste as an indicator for pro-environmental behavior and the computer and internet skills in several European countries. With the help of the panel data analysis in Stata 13, there have been developed 10 panel regression models having the recycling rate as a dependent variable and the percentage of people having different e-skills as independent variables. Relying on the results and the analysis, conclusions and recommendations for all interested parties (academia, business environment, government authorities, etc) have been formulated at the end of the paper.

\section{Literature Review}

\subsection{The importance of recycling}

Diminishing the amount of the waste set in landfills is one of the matters to handle and it enhances the quality of the environment (Izagirre-Olaizola et al., 2014). Within this frame of reference, the process of recycling has arisen as an encouraging strategy for waste management (Rhodes et al., 2015). For this reason, the recycling process of waste has grown into a universal practice within the last decades. Governments' actions are in a great extent responsible for this tendency (Kinnaman et al., 2014) and many countries in the world establish recycling objectives. For example, the main features of the revised legislative proposals on waste, included in the challenging 2018 circular economy package adopted by the European Commission are: common EU targets for recycling $65 \%$ of municipal waste, and $75 \%$ of packaging waste respectively by 2030 (European Commission, 2017). All the analogous sets of norms and standards aiming recycling indicators from various countries have delivered in time better recycling rates. This indicator 
Panel Data Analysis for Measuring the Impact of E-skills on the Ecological

Behavior of Individuals

is defined as the quantity of material recycled divided by the total quantity of waste material, according to Kinnaman et al. (2014).

Many scholars concur the fact that nearly all of the environmental issues occurring nowadays, primarily emerge from the quotidian actions of all human beings, encompassing consumption, waste disposal, travel, and energy usage (Klöckner and Oppedal, 2011). Nevertheless, a considerable number of studies have continually shown that the inhabitants are reluctant to recycle household waste. For instance, pioneer research has reflected that people consider recycling as expensive, troublesome and messy as well as time wasting. Moreover, people perceive that it demands a significant quantity of struggle to arrange, classify, stock and transport recyclable pieces to a recycling hub (Ramayah et al., 2012). As Boldero (1995) mentions, such attributes confer originality to recycling and differentiate it from other kinds of behavior due to its recurrent character. Consequently, it is credible to regard the processes of separating glass, metals, papers, plastics and other recyclable elements from household waste as a distinctive behavior in comparison with other types of pro-environmental behavior (Oztekin et al., 2017). Actually, determining the factors that influence recycling behavior represents an increasing research field in the areas of environmental psychology and education and it will be further examined in this paper.

\subsection{Approaches on recycling}

Since the number of the planet's inhabitants kept on a trend of constant increase and in the same time there is a growing material consumption, the attention of political decision makes and scientists have focused on the concerns regarding waste formation, dumping and recycling (Seacat\& Northrup, 2010).

As indicated by Daiet al. (2015), in order for the recycling process to turn into a fortunately set up operation, it is essential to own a processing infrastructure, demand for products, commercial possibilities, collection facilities and appropriate legislation and enforcement. Nevertheless, in spite of the existence of such conditions, the goal could not be achieved if the individuals do not join forces, by classifying and splitting their waste. The private households are accountable for fulfilling the main separation of waste in their own homes, by dividing recyclable items from the rest of the waste, by appropriately arranging pieces in order to be collected (some need to be cleaned or compressed) and by placing them in the accurate trash container close to the drop-off collecting point. As stated by Miranda-Carreno and Blanco-Suarez (2010), the contribution of domestic establishments constitutes a pillar in attaining larger recovery of recyclables of proper state with limited or insignificant necessity for additional sorting, thereby raising the efficiency and diminishing the expenses of the whole waste recycling operation.

Various authors have dedicated meaningful consideration in the former three decades to determine and portray the important socio-psychological and situational 
factors and obstacles of domestic recycling actions. They identified the following as influencers: age, gender, financial and educational achievements, manner of thinking about society, lifestyle, knowledge, willingness, social impact and recycling service features (Varotto\&Spagnolli, 2017). A study conducted by Guerrero et al. (2013) stated that waste production is impacted by family size, their educational level and monthly revenues. Furthermore, different features like peer impact, land dimension, household spot or the affiliation within an environmental organization account for the household waste usage and separation actions.

Jesson et al. (2014) organized the essential difficulties of recycling in four categories: circumstantial difficulties (inappropriate containers, space shortage within people's homes, irresponsible collecting etc.); behavioral difficulties (disorder within the domestic establishments, time deficit or absence of a household routine etc.); educational difficulties (not being aware what items to recycle or the main details of the recycling procedures) and attitude difficulties (not being convinced on the environmental advantages and nonexistence of compensation or acknowledgement for involvement). In a wider perspective, Trudgill (1990) suggested six groups of obstacles to common pro-environmental attitudes: acceptance (recognition of the problem's existence and its significance); awareness (of origin, effects and potential remedies); social (ethical inferences of operations); technological (accessibility and applicability of solutions); financial (division of expenses); and political (authority sharing and readiness to work out the issues).

\subsection{E-skills within the context of recycling behavior}

Since a notable amount of studies have designated a positive relation between pro-environmental behavior and recycling, several scientific directions assert that public education on recycling brought forth by the mass media through web sites, television commercial messages and advertisements in public spaces/ locations or transportation means could have a valuable and beneficial result in raising awareness on the matter (Park, 2018). Several studies have shown that education has a significant influence on the recycling rates (Pelau \& Chinie, 2018). Taking these matters about education into consideration, Europe's shift to a knowledge-based society requires a change when it comes to its education infrastructure. As up-to-date inquiries have broadly been emphasized (Empirica, 2009), Europe's aspirations to emerge as a global trendsetter in knowledge and innovation have been deeply hold up by a deficiency of proper skills, i.e. e-skills. Not near from representing a 'problem of the IT area', Europe's increasing e-skills crisis is harming the productive capacity and the competitiveness of all sorts of organizations from various kinds of areas (van Welsum\&Lanvin, 2012). Therefore, when studying the impact of education on recycling, it is decisive to analyze the importance of e-skills within the framework of education received by the people involved within the samples of different studies including the ones of the present research. 
Panel Data Analysis for Measuring the Impact of E-skills on the Ecological Behavior of Individuals

Since 2004, the European e-Skills Forum has differentiated three groups of e-skills: ICT user skills; ICT practitioner skills; and E-business skills (a cross between the technology and business skills categories). This delimitation has been applied in an abundance of scientific works developed by many institutions and stakeholders in Europe until today and it covers three main categories (Gareis et al., 2014): the ICT practitioner skills uncover the competences entailed for producing, exploring, expanding, configuring, strategic mapping, leading, advertising, selling, maintaining and assisting ICT systems. The second type unfolds the ICT user skills which stand as the aptitudes demanded for the people's adequate usage of ICT systems and devices. ICT users apply systems as instruments in reinforcement of their own tasks. User skills encase the practice of common software tools and of specialized tools supporting business functions within industry. Overall, they encircle the notion of "digital literacy": the skills needed for the assertive and analytical use of ICT for work, learning, communication and recreation. The third category encompasses the EBusiness/Leadership skills which represent a series of expertise, attributes and viewpoints linked to: the knowledge on the potential and shortcomings of software and information systems in practice, the skills to rapidly evaluate new abilities of current systems and the significance of propositions of software and web services rising on the market, the capability to depict prototype alternatives and to perceive the keys of arrangement of business and IT functions in an organization.

It is important to mention that, because the concept of "e-skills" is a relatively new one, very few studies have been conducted on the influence of these capabilities on pro-environmental behaviour with none being carried out regarding the influence over the recycling process specifically. However, Bill Tomlinson's (2010) book Greening through IT is one of the first books on ICT for sustainability and it investigates a diversity of possible positive leverages of ICT on the environment. One of the areas which is deepened in extent is education, with emphasis on gaining different types of skills from which e-skills hold a distinctive weight within the framework of the knowledge-based economy. The same focus is put in the scientific papers of Cornell \&Berkhout (2013) or Fuchs (2008) regarding the usage of IT for green education, for collective action, and for spreading ideas, very relevant actions for the development of the recycling process' perspectives.

Some of the most relevant e-skills, which if improved by users can also cultivate their recycling behaviour, are connected to ICT usage, such as computers, portable devices, software and the internet, and they revolve around: searching and uncovering recycling related information on the internet (for example from egovernment websites), participation in pro-environmental social networks, usage of online learning material about recycling, communication with other users interested in the topic, usage of software to edit photos, video or audio files in order to create materials about recycling with the aim of raising awareness within the communities (Zupan, 2016). 
Roughly, the vision of the revised legislative proposals on waste included in the challenging 2018 circular economy package adopted by the European Commission definitely involves sustainable solutions through innovation. Greenprocesses overall represent a chance and also a responsibility for the IT industry and therefore effective support for the recycling processes as well will of course demand the advancement of the correlated e-skills competencies (McCormack, 2010).

\section{Research Methodology \\ 3.1 Hypotheses of the research}

The objective of our research has been to determine the relation between the computer and internet skills on the recycling rate in the society. We have defined our hypothesis based on the premise that people with better computer and internet skills have better access to information and therefore are more willing to recycle. Moreover, people having higher computer and internet skills have rather the tendency to store documents in a digital way and therefore have the tendency to print less. Starting from this objective, we have developed the following six hypotheses, out of which three are based on the computer skills and three of them are based on the internet skills: recycle

H1a: People with basic PC skills (1-2 skills) have a higher tendency to

H1b: People with an average number of PC skills (3-4 skills) have a higher tendency to recycle

H1c: People with a high number of PC skills (5-6 skills) have a higher tendency to recycle recycle

H2a: People with basic internet skills (1-2 skills) have a higher tendency to

H2b: People with an average number of internet PC skills (3-4 skills) have a higher tendency to recycle

H2c: People with a high number of internet skills (5-6 skills) have a higher tendency to recycle

The premise for our hypotheses is the fact that higher computer and internet skills, have a higher influence on the willingness to recycle and on the proenvironmental behaviour. These hypotheses are based on researches which show that the recycling willingness and the pro-environmental behaviour depends on socio-demographic and cultural factors as well as education and IQ level.

3.2. The panel data analysis model

For the objective of the research and for the defined hypotheses, we have developed two panel data analysis model. For hypotheses H1a, H1b and H1c we have defined the following panel data analysis model:

$X_{\text {recyc,it }}=\beta_{1} X_{\mathrm{PC} 1-2, \mathrm{it}}+\beta_{2} \mathrm{X}_{\mathrm{PC} 3-4, \mathrm{it}}+\beta_{3} \mathrm{X}_{\mathrm{PC} 5-6, \mathrm{it}}+\beta_{4} \mathrm{X}_{\mathrm{LivC} \text { Cond,it }}+\beta_{5} \mathrm{X}_{\mathrm{EDU} 5-8, \mathrm{it}}+\mathrm{c}_{1}$

having $\mathrm{i}=$ number of countries included in the analysis, $\mathrm{t}=$ time unit for the analyzed period 
Panel Data Analysis for Measuring the Impact of E-skills on the Ecological Behavior of Individuals

In the first model, we have considered the recycling rate of municipal waste as the dependent variable and the percentage of a population having different levels of computer skills (PC skills) in different European countries as independent variables. We have therefore, three independent variables, namely the percentage of people having 1-2 computer skills, the percentage of people having 3-4 computer skills and the percentage of the population having 5-6 computer skills. For this model, we have also included two control variables, namely the living conditions in the society and the percentage of people having university education. For each of the independent variables, we have defined the coefficients $\beta_{i}, i=1, \ldots, 5$ and the constant $c_{1}$. The validity of the model will be measured by determining the significance of the $\beta$ coefficients. This will be done by using the panel data analysis in the program Stata 13.0.

For the influence of the internet skills on the recycling behaviour and for the hypotheses $\mathrm{H} 2 \mathrm{a}, \mathrm{H} 2 \mathrm{~b}$ and $\mathrm{H} 2 \mathrm{c}$, we have developed the following panel data analysis model:

$$
\begin{aligned}
& c_{2} X_{\text {recyc,it }}=\beta_{6} X_{\text {Internet1-2,it }}+\beta_{7} X_{\text {Internet3-4,it }}+\beta_{8} X_{\text {Internet5-6,it }}+\beta_{9} X_{\text {LivCond,it }}+\beta_{10} X_{\text {Edu3-4,it }}+ \\
& \text { having } \quad \begin{array}{l}
i=\text { number of countries included in the analysis, } \\
t=\text { time unit for the analyzed period }
\end{array}
\end{aligned}
$$

In the second panel data analysis model, we have considered the recycling rate of municipal waste, again as the dependent variable. In this model the three independent variables are the percentage of people having 1-2 internet skills, the percentage of people having 3-4 internet skills and the percentage of people having 5-6 internet skills in different European countries. For a better accuracy of the model, we have considered the living conditions and the education level 3-4 as control variables. For the independent variables, there have been defined the coefficients $\beta_{\mathrm{i}}, \mathrm{i}=6, . ., 10$ and the constant $\mathrm{c}_{2}$. With the help of the panel data analysis (Baltagi, 2008) in the program Stata 13.0, we will measure the significance of these coefficients. For both models, we have used the random effect.

\subsection{Data collection}

The research has been carried out based on statistical data from Eurostat (2018). The dependent variable recycling rate describes the percentage of recycled municipal waste from the total waste within an economy. The independent variables refer to the percentage of population (from the total population) which is able to master a certain number of computer or internet skills out of the six defined by the European Commission (2014). For both the computer and the internet skills, 
there are defined 3 categories: 1-2 out of six skills, 3-4 out of six skills and 5-6 out of six skills.

In order to increase the validity of the model, we have used three control variables. The control variable called living conditions, defined by the average number rooms per person, has been included in both panel regression models. Besides this, we have included the education level 3-4 (according to ISCED11) as a control variable in the model having the internet skills as independent variables and the education level 5-8 (according to ISCED11) as a control variable in the model having the computer skills as dependent variable. All control variables have been selected based on their significance level in the regression. A description of the variables included in the model can be observed in table 1 .

\section{Table 1: Definition of variables}

\begin{tabular}{|c|c|c|c|c|c|c|c|c|c|c|c|c|}
\hline Variable code & Variable name & $\mathbf{D}$ & $\mathbf{e}$ & $\mathbf{S}$ & c & $\mathbf{r}$ & $\mathbf{i}$ & p & $\mathbf{t}$ & $\mathbf{i}$ & $\mathbf{0}$ & $\mathbf{n}$ \\
\hline $\mathbf{X}$ r e c c y c & Recycling rate* & \multicolumn{11}{|c|}{ 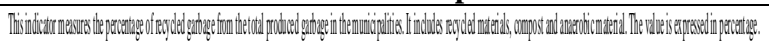 } \\
\hline $\mathbf{X} \mathbf{P} \mathbf{C}-\mathbf{1}-\mathbf{2}$ & E-skill-1-2-PC* & \multicolumn{11}{|c|}{ Percentage of population, which is able to carry out 1 or 2 of the 6 computer related activities } \\
\hline$X$ P C $-3-4$ & E-skill-3-4-PC * & \multicolumn{11}{|c|}{ Percentage of population, which is able to carry out 3 or 4 of the 6 computer related activities } \\
\hline$X$ P C $-5-6$ & E-skill-5-6-PC* & \multicolumn{11}{|c|}{ Percentage of population, which is able to carry out 5 or 6 of the 6 computer related activities } \\
\hline X Internet-1-2 & E-skill-1-2-Internet* & \multicolumn{11}{|c|}{ Percentage of population, which is able to carry out 1 or 2 of the 6 internet related activities } \\
\hline X Internet-3-4 & E-skill-3-4-Internet * & \multicolumn{11}{|c|}{ Percentage of population, which is able to carry out 3 or 4 of the 6 internet related activities } \\
\hline XInternet-5-6 & E-skill-5-6-Internet* & \multicolumn{11}{|c|}{ Percentage of population, which is able to carry out 5 or 6 of the 6 internet related activities } \\
\hline$X$ e d u $3-4$ & Education level 3-4* & \multirow{3}{*}{\multicolumn{11}{|c|}{ 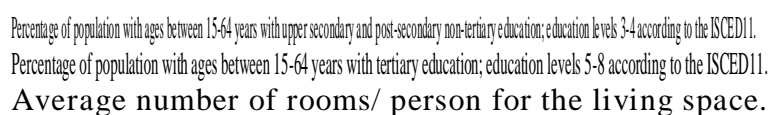 }} \\
\hline$X$ e d u $5-8$ & Education level 5-8* & & & & & & & & & & & \\
\hline Xivivond & Living conditions* & & & & & & & & & & & \\
\hline
\end{tabular}

*Source: Eurostat Database (2018)

The data used in the two panel analysis models has been provided by the Eurostat Database (2018) for the period 2005-2014. The panel consisted out of the following 30 countries: Austria, Belgium, Bulgaria, Croatia, Cyprus, Czech Republic, Denmark, Estonia, Finland, France, Germany, Greece, Hungary, Iceland, Ireland, Italy, Latvia, Lithuania, Luxembourg, Malta, Netherlands, Norway, Poland, Portugal, Romania, Slovakia, Slovenia, Spain, Swedenand United Kingdom. There has to be mentioned that the data for the computer skills and the internet skills were not provided for the entire analysed period. For the computer skills we have analysed data from 7 years in the analysed period (111 observations), while for the internet skills, we have analysed data from 6 years in the analysed period (84 observations). Taking into consideration the fact, that especially in the last years the data has been collected every two years (different years for computer and internet skills), it was not possible to develop a combined model. 
Panel Data Analysis for Measuring the Impact of E-skills on the Ecological Behavior of Individuals

\section{Results of the panel data model \\ 4.1. Descriptive statistics of the data}

The descriptive statistics of the variables can be observed in Table 2. For the dependent variable recycling rate, the mean value is $\mathrm{M}_{\text {recyc }}=30.32$ and the standard deviation is $\mathrm{SD}_{\text {recyc }}=16.32$. The minimum value of $\mathrm{Min}_{\text {recyc }}=0.4$ is reached by Romania in 2007, while is maximum value of $M_{\text {ax }}{ }_{\text {recyc }}=65.6$ is reached by Germany in 2014. For the independent variables, we have the following descriptive values. The percentage of population having 1-2 computer skills has a mean value of $\mathrm{M}_{\mathrm{PCl}-2}=13.92$ and $\mathrm{SD}_{\mathrm{PCl}-2}=3.33$. The minimum value $\mathrm{Min}_{\mathrm{PC1}-2}=8.0$ has been achieved by Italy (2007), Croatia (2009), Lithuania (2009) and Greece (2012). The maximum value $\mathrm{Max}_{\mathrm{PC1}-2}=23.0$ has been achieved by Sweden (2009) and Belgium (2014). The mean value of the variable percentage of people having 3-4 out of six defined computer skills is $\mathrm{M}_{\mathrm{PC} 3-4}=24.53$, having a standard deviation $\mathrm{SD}_{\mathrm{PC} 3-4}=6.02$.

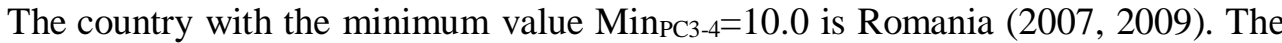
country having the maximum value of $\mathrm{Max}_{\mathrm{PC} 3-4}=36.0$ is Iceland (2009). The average value of the percentage of population being able to perform 5-6 of the six defined computer skills is $\mathrm{M}_{\mathrm{PC} 5-6}=27.56$, with $\mathrm{SD}_{\mathrm{PC} 5-6}=9.16$. The minimum value Min ${ }_{\mathrm{PC} 5-}$ ${ }_{6}=5.0$ is obtained by Romania in 2007, while its maximum value of Max ${ }_{\text {PC5 }-6}=46.0$ is obtained by Finland in 2014.

For the internet skills, there are the following descriptive indicators. For the variable percentage of people having 1-2 out of 6 internet skills, the mean has the value $\mathrm{M}_{\text {Internet1-2 }}=27.41$ and the standard deviation $\mathrm{SD}_{\text {Internet1-2 }}=8.07$. The countries having the minimum value $\operatorname{Min}_{\text {Internet1-2 }}=12.0$ are Latvia (2011) and Lithuania (2013). The country with the maximum value $\operatorname{Max}_{\text {Internet1-2 }}=48.0$ is Finland (2010). The average value for the variable 3-4 out of 6 internet skills is $M_{\text {Internet3-4 }}=30.94$, having a $\mathrm{SD}_{\text {Internet3-4-4 }}=8.66$. The minimum value $\mathrm{Min}_{\text {Internet3-4}}=10.0$ is reached by Romania in 2007. The maximum value Max Internet3-4 $=50.0$ is reached by Denmark in 2013. The average for the variable 5-6 out of 6 Internet skills is $M_{\text {Internet5- } 6=12.71 \text {. }}$ The minimum value is $\mathrm{Min}_{\text {Internet5-6}}=1.0$ and it has been calculated in Romania in 2010. The maximum value of $\operatorname{Max}_{\text {Internet5- }-6}=34.0$ and has been calculated in Iceland in 2013.

Table 2: Descriptive statistic of variables

\begin{tabular}{|c|c|c|c|c|c|c|c|c|c|c|c|c|c|c|}
\hline $\begin{array}{llllllll}\mathrm{V} & \mathrm{a} & \mathrm{r} & \mathrm{i} & \mathrm{a} & \mathrm{b} & \mathrm{l} & \mathrm{e} \\
\end{array}$ & $\mathrm{M}$ & $\mathrm{e}$ & $\mathrm{a}$ & $\mathrm{n}$ & \multicolumn{3}{|c|}{ Minimum } & \multicolumn{3}{|c|}{ Maximum } & \multicolumn{4}{|c|}{ Standard Deviation } \\
\hline Recycling rate & 3 & 0 & 3 & 2 & 0 & & 4 & 6 & 5 & 6 & 1 & $\overline{6}$ & 3 & 2 \\
\hline E-s k i $11-1-2-P$ C & 1 & 3 & 9 & 2 & 8 & & 0 & 2 & 3 & 0 & 3 & & 3 & 3 \\
\hline E-s kill-3-4-P C & 2 & 4 & 5 & 3 & 1 & 0 & 0 & 3 & 6 & 0 & 0 & & 0 & 2 \\
\hline E-s k i $11-5-6-P C$ & 2 & 7 & 5 & 6 & 5 & & 0 & 4 & 6 & 0 & 9 & & 1 & 6 \\
\hline E-skill-1-2-Internet & 2 & 7 & 4 & 1 & 1 & 2 & 0 & 4 & 8 & 0 & 8 & & 0 & 7 \\
\hline E-skill-3-4-Internet & 3 & 0 & 9 & 4 & 1 & 0 & 0 & 5 & 0 & 0 & 8 & & 6 & 6 \\
\hline E-skill-5-6-Internet & 1 & 2 & 7 & 1 & 1 & & 0 & 3 & 4 & 0 & 0 & & 3 & 3 \\
\hline
\end{tabular}


Daniela Serban, Corina Pelau, Violeta Dinca

\begin{tabular}{|c|c|c|c|c|c|c|c|c|c|c|c|c|c|}
\hline Education level 3-4 & 47 & & 62 & 1 & 6 & 6 & & 2 & 2 & 1 & 2 & 7 & 4 \\
\hline Education level 5-8 & 23 & 5 & 53 & 9 & & c & & 9 & 6 & 6 & . & 9 & 3 \\
\hline Living conditions & 1 & 6 & 1 & 1 & & c & & . & 3 & 1 & . & 6 & 1 \\
\hline
\end{tabular}

For the control variables, there are the following values. The variable education level 3-4 has a mean value of $\mathrm{M}_{\text {edu3 }-4}=47.62$ and a standard deviation of $\mathrm{SD}_{\text {edu3 }-4=12.74}$. The minimum value $\mathrm{Min}_{\text {edu3 }-4=12.74}$ is reached by Portugal (2007), while the maximum value of $\mathrm{Max}_{\text {edu3-4}}=72.2$ has been calculated in Czech Republic (2007). The control variable education level 5-8 (university education) has a mean value of $\mathrm{M}_{\text {edu5- } 8}=23.53$ and a standard deviation of $\mathrm{SD}_{\text {edu5- } 8=6.93 \text {. The minimum }}$ value $\mathrm{Min}_{\text {edu5-8}}=9.9$ has been observed in Romania (2007) and the maximum value $\operatorname{Max}_{\text {edu5-8 }}=39.6$ in Luxemburg (2014). The variable living conditions has an average value of $\mathrm{M}_{\text {livcond }}=1.61$, a minimum value of $\mathrm{Min}_{\text {livcond }}=1.0$ and a maximum value of $\operatorname{Max}_{\text {livcond }}=2.3$ in Belgium in several years.

In table 3 and in table 4, there can be observed the correlation matrices for the two models. For the model having the e-skills as independent variable all correlation coefficients have values lower than 0.65 . These values show no pairwise correlation between the variables, showing that there is an adequate use of the independent variables in the model.

Table 3: Correlation matrix for variables

\begin{tabular}{|c|c|c|c|c|c|}
\hline $\mathrm{V}$ a $\mathrm{r}$ i a b l e & E-skill-1-2-PC & E-skill-3-4-PC & E-skill-5-6-PC & Education 5-8 & Living conditions \\
\hline E-skill-1-2-PC & 1.0000 & & & & \\
\hline E-skill-3-4-PC & 465 & $\begin{array}{lll}0 & 0 & 0\end{array}$ & & & \\
\hline E-skill-5-6-PC & -0.071 & $\begin{array}{lll}6 & 1 & 4\end{array}$ & $\begin{array}{lll}0 & 0 & 0\end{array}$ & & \\
\hline Education 5-8 & 0.178 & $\begin{array}{lll}5 & 29\end{array}$ & 642 & $\begin{array}{lll}0 & 0 & 0\end{array}$ & \\
\hline Living conditions & 202 & $\begin{array}{lll}5 & 9 & 3\end{array}$ & $\begin{array}{lll}5 & 8 & 0\end{array}$ & $\begin{array}{lll}6 & 1 & 7\end{array}$ & $\begin{array}{ll}0 & 0\end{array}$ \\
\hline
\end{tabular}

Table 4: Correlation matrix for variables

\begin{tabular}{|c|c|c|c|c|c|}
\hline $\mathrm{V}$ a $\mathrm{r}$ i a b l e & E-skill-1-2-Interent & E-skill-3-4-Internet & E-kkill-5-6-Internet & Education 3-4 & Living conditions \\
\hline E-skill-1-2-Internet & 1.0000 & & & & \\
\hline E-skill-3-4-Internet & 0.338 & $\begin{array}{llll}1 . & 0 & 0 & 0\end{array}$ & & & \\
\hline E-skill-5-6-Internet & -0.332 & 0.473 & 1.000 & & \\
\hline Education 3-4 & $\begin{array}{lllll}0.0 & 2 & 4\end{array}$ & -0.161 & -0.082 & $\begin{array}{lll}0 & 0 & 0\end{array}$ & \\
\hline Living conditions & $\begin{array}{lll}5 & 3 & 5 \\
\end{array}$ & $\begin{array}{llll}0.5 & 5 & 5 \\
\end{array}$ & $\begin{array}{lll}0 & 4 & 7 \\
\end{array}$ & -0.594 & $\begin{array}{lll}0 & 0 & 0 \\
\end{array}$ \\
\hline
\end{tabular}

For the model having the internet skills as independent variables, the correlation matrix also shows an adequate use of the variables. In this case all correlation coefficients have values lower than 0.6 , showing a medium to low level correlation. 
Panel Data Analysis for Measuring the Impact of E-skills on the Ecological Behavior of Individuals

\subsection{Panel data analysis model with the PC skills as dependent variable}

In order to test our first group of hypotheses (H1a, H1b, H1c) defining the relation between the dependent variable recycling rates, the independent variables regarding the e-skills of the population and the chosen control variables, several panel data analysis models have been developed. Both models have been tested with one independent variable (ceteris paribus) as well as combined models, as it can be observed in Table 5.

Model 1 describes the regression having the independent variable percentage of people having 1-2 PC-skills as ceteris paribus variable and the recycling rate as dependent variable. The Wald-chi2 value $=79.65(\mathrm{p}=0.000)$ and the rho $=0.902$ show a high adequacy of this model. The $\beta$-coefficient for the independent variable 1-2 E-skills has a value of $\beta_{1}=0.37(\mathrm{z}=1.94, \mathrm{p}=0.052<0.10)$ proving also relevancy for the model. The high significance of the $\beta$-coefficient of the control variables living conditions $\left(\beta_{4}=21.27, \mathrm{z}=5.44, \mathrm{p}=0.000\right)$ and education level 5-8 $\left(\beta_{5}=0.53, \mathrm{z}=3.02, \mathrm{p}=0.002\right)$ and the constant $\mathrm{c}_{1}=-21.5(\mathrm{z}=-3.39, \mathrm{p}=0.001)$ also sustain the robustness of the model. Model 1 has an $\mathrm{R}$-sq=0.481, showing that the independent variable 1-2 PC-skills together with the control variables living conditions and university education can determine $48.1 \%$ of the value of the independent variable.

In second model is analyzed the panel regression between the percentage of people having 3-4 e-skills as a ceteris paribus independent variable and the recycling rate as a dependent variable. Model 2 shows a higher significance in comparison to model 1 , having higher values for both the Wald chi2 $=88.2$ $(\mathrm{p}=0.000)$ and $\mathrm{rho}=0.905$. The $\beta$-coefficient for the variable 3-4 PC skills has also a higher significance by having $\beta_{2}=0.66(\mathrm{z}=2.99, \mathrm{p}=0.003<0.01)$. Similar to model 1 , the control variables living conditions $\left(\beta_{4}=19.17, \mathrm{z}=4.90, \mathrm{p}=0.000\right)$ and education level 5-8 $\left(\beta_{5}=0.44, \mathrm{z}=2.52, \mathrm{p}=0.012\right)$ show also a high significance level. Model 2 has also a higher $\mathrm{R}$-sq $=0.509$ in comparison to the first model, so quality of the second model improved.

Table 5: Panel regression model for the dependent variable recycling rate

\begin{tabular}{|c|c|c|c|c|c|}
\hline 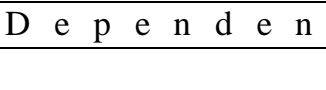 & $\begin{array}{l}\mathrm{t} \quad \mathrm{v} \text { a } \mathrm{r} \\
\text { Model } 1\end{array}$ & $\begin{array}{cccc}\mathrm{i} & \mathrm{a} \quad \mathrm{b} & \mathrm{l} & \mathrm{e} \\
\text { Model } & 2\end{array}$ & $\frac{\mathrm{R} \text { e } \mathrm{c} y}{\text { Model } 3}$ & $\begin{array}{c}\mathrm{c} \text { l } \mathrm{i} \text { n } \mathrm{g} \\
\text { Model } 4\end{array}$ & $\begin{array}{rr}\mathrm{r} \text { a t } & \mathrm{e} \\
\text { Model } & 5\end{array}$ \\
\hline E-skill-1-2-PC & $\begin{array}{l}0.37 * \\
(1.94)\end{array}$ & & & 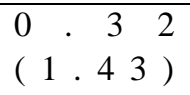 & 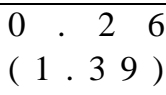 \\
\hline E-s ki $11-3-4-P C$ & & $\begin{array}{l}0.66 * * * \\
(2.99)\end{array}$ & & $\begin{array}{l}0.60 * * * \\
(2.66)\end{array}$ & $\begin{array}{l}0.60 * * * \\
(2.65)\end{array}$ \\
\hline E-s ki $11-5-6-P C$ & & & $\begin{array}{l}-0.08 \\
(-0.79)\end{array}$ & $\begin{array}{l}0.45 \\
(0.49)\end{array}$ & \\
\hline Living conditions (rooms/ pers) & $\begin{array}{l}21.27 * * * \\
(5.44)\end{array}$ & $\begin{array}{l}19.17 * * * \\
(4.90)\end{array}$ & $\begin{array}{l}22.28 * * * \\
(5.52)\end{array}$ & $\begin{array}{l}18.63 * * * \\
(4.61)\end{array}$ & $\begin{array}{l}19.09 * * * \\
(4.90)\end{array}$ \\
\hline
\end{tabular}


Daniela Serban, Corina Pelau, Violeta Dinca

\begin{tabular}{|c|c|c|c|c|c|}
\hline Education level 5-8 & $\begin{array}{l}0.53 * * * \\
(3.02)\end{array}$ & $\begin{array}{l}0.44 * * \\
(2.52)\end{array}$ & $\begin{array}{l}0.66 * * * \\
(3.54)\end{array}$ & $\begin{array}{l}0.36 * \\
(1.86)\end{array}$ & $\begin{array}{l}0.41 * * \\
(2.32)\end{array}$ \\
\hline $\mathrm{C} \quad \mathrm{o} \quad \mathrm{n} \quad \mathrm{s} \quad \mathrm{t} \quad \mathrm{a} \quad \mathrm{n} \quad \mathrm{t}$ & $\begin{array}{l}-21.5 * * * \\
(-3.39)\end{array}$ & $\begin{array}{l}-27.25 * * * \\
(-4.06)\end{array}$ & $\begin{array}{l}-18.55 * * * \\
(-2.93)\end{array}$ & $\begin{array}{l}-29.18 * * * \\
(-4.21)\end{array}$ & $\begin{array}{l}-28.43 * * * \\
(-4.22)\end{array}$ \\
\hline Random effect & e $\mathrm{s}$ & $\mathrm{Y}$ & $\mathrm{Y}$ & $\mathrm{Y}$ & $\mathrm{Y}$ \\
\hline $\mathrm{W}$ a $1 \mathrm{~d} \quad \mathrm{c} \mathrm{h}$ i 2 & $79.65 * * *$ & $88.20 * * *$ & $73.94 * * *$ & $90.24 * * *$ & $90.87 * * *$ \\
\hline $\mathrm{s}$ & 0.481 & $\begin{array}{lll}5 & 0 & 9\end{array}$ & 0.451 & $\begin{array}{lll}5 & 2 & 1\end{array}$ & 520 \\
\hline $\mathrm{h}$ & 0.902 & 905 & $\begin{array}{lllll}0 & 9 & 9 & 9\end{array}$ & 9009 & 906 \\
\hline Observations & $\begin{array}{lll}1 & 1 & 1\end{array}$ & 1 & 1 & 1 & 1 \\
\hline
\end{tabular}

Model 3, having the independent variable 5-6 PC-skills as ceteris paribus, has the lowest significance. Model 3 has the lowest value for Wald chi2 $=0.73 .94$ $(p=0.000)$ and the lowest significance for the $\beta$-coefficient. The independent variable 5-6 PC-skills has $\beta_{3}=-0.08(\mathrm{z}=-0.79, \mathrm{p}=0.431>0.1)$ showing no relevant significance. The control variables and the constant have similar values to the previous model $\left(\beta_{4}=22.28, \mathrm{z}=5.42, \mathrm{p}=0.000\right.$ for the living conditions; $\beta_{5}=0.66$, $\mathrm{z}=3.54, \mathrm{p}=0.000$ for the education level $5-8$ and $\mathrm{c}_{1}=-18.55, \mathrm{z}=-2.93, \mathrm{p}=0.003$ ). For this model the $\mathrm{R}-\mathrm{sq}=0.451$ has also the lowest value compared to the other models, showing the lowest quality model by now.

In order to analyze the combined value of the independent variables, there have been also developed model 4 , having all independent variables included in the model and model 5, having only the significant variables (1-2 PC-skills and 3-4 PCskills) included in the model.

Model 4, including all three independent variables related to the PC-skills, shows a high significance based on the Wald - chi $2=90.24(\mathrm{p}=0.000)$ and $\mathrm{rho}=0.909$. Despite this, the $\beta$-coefficients for two of the three variables have low significances. The only variable with a high significance in this combined model, is the independent 3-4 PC-skills. For this variable the coefficient $\beta_{2}=0.60 \quad(\mathrm{z}=2.66$, $\mathrm{p}=0.008<0.01)$ has similar value to the previous model. The other two variables, $1-2$ PC-skills $\left(\beta_{1}=0.32, \mathrm{z}=1.43, \mathrm{p}=0.153\right)$ and 5-6 PC-skills $\left(\beta_{3}=-0.08, \mathrm{z}=-079, \mathrm{p}=0.626\right)$ don't have relevant $\beta$-coefficient. For the control variable percentage of people having university education, there is also a decrease of relevance compared to the other models having $\beta_{5}=0.36, \mathrm{z}=1.80, \mathrm{p}=0.072$ ).

Based on all these result, we have developed model 5 having only two independent variables namely the percentage of people having 1-2 PC-skills and those having 3-4 PC-skills. For model 5 the values of Wald-chi2 $=90.87(\mathrm{p}=0.000)$ is the highest and the $\mathrm{R}-\mathrm{sq}=0.520$ has also a comparable high value, explaining more than half of the regressor's variation. The $\beta$-coefficient for the variable 3-4 skills has the significant value of $\beta_{2}=-0.60(\mathrm{z}=2.65, \mathrm{p}=0.008)$. The independent variable 1-2 PC-skills doesn't show significant $\beta$-coefficient values, having $\beta_{1}=-0.26(\mathrm{z}=1.39$, $\mathrm{p}=0.165)$. The control variables $\left(\beta_{4}=19.09, \mathrm{z}=4.90, \mathrm{p}=0.000\right.$ for the living 
Panel Data Analysis for Measuring the Impact of E-skills on the Ecological Behavior of Individuals

conditions; $\beta_{5}=0.41, \mathrm{z}=2.32, \mathrm{p}=0.020$ for the education level 5-8) have better significance values compared to model 4 .

\subsection{Panel data analysis model with the internet skills as dependent Variable}

The second panel data analysis model has been developed in order to test the second set of hypothesis $(\mathrm{H} 2 \mathrm{a}, \mathrm{H} 2 \mathrm{~b}$ and $\mathrm{H} 2 \mathrm{c})$ regarding the relation between the recycling rate as a dependent variable and the percentage of people having different levels of internet skills as independent variables. In order to test the three hypotheses, there have been developed five models, three of them having only one independent variable and two combined models as it can be observed in table 6 .

In model 6 , there can be observed the ceteris paribus relation between the recycling rate of municipal waste in an economy as a dependent variable and the percentage of people having only 1-2 internet skills as an independent variable. For the consistency of the model, we have also included the living conditions and the percentage of people having an education of level 3-4 (high school or similar). The significance of the model is given by the Wald-chi2 $=68.99(\mathrm{p}=0.000)$ and the rho $=0.903$. The $\beta$-coefficient for the independent variable 1-2 internet-skills has a value of $\beta_{6}=0.15$ ( $\left.\mathrm{z}=1.60, \mathrm{p}=0.109\right)$ showing acceptable values for the model. The control variables living conditions $\left(\beta_{9}=30.73, \mathrm{z}=7.98, \mathrm{p}=0.000\right)$, percentage of people with education level 3-4 $\left(\beta_{10}=0.35, \mathrm{z}=2.19, \mathrm{p}=0.028<0.05\right)$ and the constant $\mathrm{c}_{2}=-40.21(\mathrm{z}=-3.33, \mathrm{p}=0.001<0.01)$ have also significant values. For this model, there is also the highest $\mathrm{R}$-sq $=0.563>0.5$, compared to the other models in Table 6 .

Model 7 describes the relation between the percentage of people having 3-4 internet-skills as a ceteris paribus independent variable and the recycling rate in an economy as a dependent. The Wald-chi $2=66.76(\mathrm{p}=0.000)$ and the rho $=0.924$ show a high adequacy of the model. For the independent variable 3-4 internet skills the $\beta$ coefficient has a value of $\beta_{7}=0.20(\mathrm{z}=1.67, \mathrm{p}=0.094)$ proving also the significance of the model. The adequacy of the model is also given by the significance of the control variables $\left(\beta_{9}=27.70, \mathrm{z}=6.61, \mathrm{p}=0.000\right.$ for the living conditions and $\beta_{10}=0.33$, $\mathrm{z}=1.93, \mathrm{p}=0.053<0.1)$ and of the constant $\left(\mathrm{c}_{2}=-36.87, \mathrm{z}=-3.01, \mathrm{p}=0.003<0.01\right)$. For this model the $\mathrm{R}-\mathrm{sq}=0.523$.

Table 6: Panel regression model for the dependent variable recycling rate

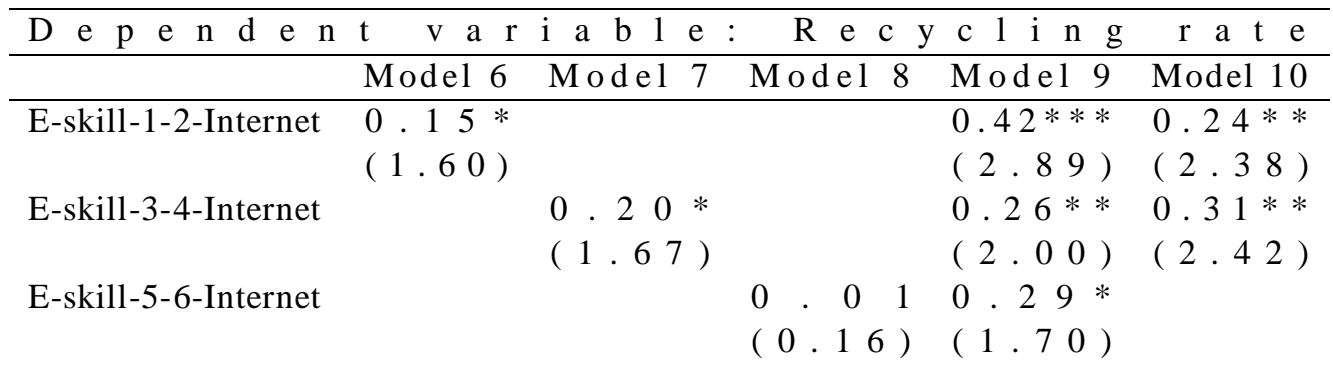


Daniela Serban, Corina Pelau, Violeta Dinca

\begin{tabular}{|c|c|c|c|c|c|}
\hline Living conditions (rooms/ pers) & $\begin{array}{l}30.73 * * * \\
(7.98)\end{array}$ & $\begin{array}{l}27.70 * * * \\
(6.61)\end{array}$ & $\begin{array}{l}30.46 * * * \\
(7.62)\end{array}$ & $\begin{array}{l}24.75 * * * \\
(5.88)\end{array}$ & $\begin{array}{l}26.25 * * * \\
(6.32)\end{array}$ \\
\hline Education level 3-4 & $\begin{array}{l}0.35 * * \\
(2.19)\end{array}$ & 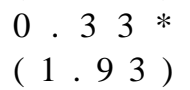 & $\begin{array}{l}0.35 * * \\
(2.08)\end{array}$ & $\begin{array}{l}0.26 * \\
(1.63)\end{array}$ & $\begin{array}{l}0.30 * \\
(1.85)\end{array}$ \\
\hline $\mathrm{C}$ o n $\mathrm{n}$ t $\mathrm{a} \quad \mathrm{n} \quad \mathrm{t}$ & $\begin{array}{l}-40.21 * * * \\
(-3.33)\end{array}$ & $\begin{array}{l}-36.87 * * * \\
(-3.01)\end{array}$ & $\begin{array}{l}-35.89 \\
(-2.91)\end{array}$ & $\begin{array}{l}-46.55 * * * \\
(-3.90)\end{array}$ & $\begin{array}{l}-43.39 * * * \\
(-3.61)\end{array}$ \\
\hline Random effect & $\mathrm{Y}$ e $\mathrm{s}$ & $\mathrm{Y}$ & $\mathrm{Y}$ & $\mathrm{Y}$ & $\mathrm{Y}$ \\
\hline $\mathrm{W}$ a $1 \mathrm{~d} \quad \mathrm{c} h$ i 2 & $68.99 * * *$ & $66.76 * * *$ & $62.36 * * *$ & $82.35 * * *$ & $77.23 * * *$ \\
\hline$-\quad s$ & 0.563 & 0.523 & 0.537 & 0.556 & 0.549 \\
\hline $\mathrm{h}$ & 0.903 & 0.924 & 920 & 912 & 915 \\
\hline Observations & 8 & 4 & 4 & 8 & 8 \\
\hline
\end{tabular}

There is no significant ceteris paribus influence of the variable percentage of people having 5-6 internet-skills on the dependent recycling rate of municipal waste in an economy, Despite the fact, that there are significant values for the Waldchi $2=62.36(\mathrm{p}=0.000)$ and $\mathrm{rho}=0.920$, the $\beta$-coefficient of the independent variable is $\beta_{8}=0.01$ ( $\left.\mathrm{z}=0.16, \mathrm{p}=0.875\right)$. Therefore, there can be considered that the variable does not have a significant influence in the model.

Model 9 and model 10 present a panel regression having a combination of the independent variables, analyzed above. In model 9, there is presented a model including all three variables related to the percentage of people having different number of internet-skills. The Wald-chi $2=82.35(\mathrm{p}=0.000)$ and $\mathrm{rho}=0.912$ show the highest significance for this model. Besides, there are significant values for the $\beta$ coefficients of all three independent variables. The variable percentage of people having 1-2 internet skills has $\beta_{6}=0.42(\mathrm{z}=2.89, \mathrm{p}=0.004)$, the percentage of people having 3-4 internet skills has $\beta_{7}=0.26(\mathrm{z}=2.00, \mathrm{p}=0.045)$, while the variable percentage of people having 5-6 internet skills has $\beta_{8}=0.29(\mathrm{z}=1.70, \mathrm{p}=0.089)$. The consistency of the model is also shown by the high significance of the control variables $\left(\beta_{9}=24.75, \mathrm{z}=5.88, \mathrm{p}=0.000\right.$ for the living conditions and $\beta_{10}=0.26, \mathrm{z}=1.63$, $\mathrm{p}=0.103$ ). The $\mathrm{R}-\mathrm{sq}=0.556$ shows a good influence of the independents on the dependent variable, giving consistency to the model.

Taking into consideration the fact that the variable percentage of people having 5-6 internet skills, had a small significance both in model 8 and model 9, we have tested a panel regression model having only the variables percentage of people having 1-2 internet skills and 3-4 internet skills as independent variables. For this model the Wald-chi=77.23 ( $\mathrm{p}=0.000)$ having a lower value compared to model 9 and a higher value compared to the ceteris paribus models (model 6, model 7 and model 8). In this case, the $\beta$-coefficients have significant values for both variables, having $\beta_{7}=0.24(\mathrm{z}=2.38, \mathrm{p}=0.017)$ for the percentage of people having 1-2 internet skills and $\beta_{8}=0.31(\mathrm{z}=2.42, \mathrm{p}=0.016)$ for the people having 3-4 internet skills. The control variables living conditions $\left(\beta_{9}=26.25, \mathrm{z}=6.32, \mathrm{p}=0.000\right)$ and education level 3-4 $\left(\beta_{10}=0.30, \mathrm{z}=1.85, \mathrm{p}=0.065\right)$ have also significant values. 
Panel Data Analysis for Measuring the Impact of E-skills on the Ecological Behavior of Individuals

\section{Conclusions}

The results of the panel data regression model show that the recycling rate in a society is influenced mostly by the percentage of people having average PC and internet skills (3-4 PC-skills and 3-4 internet skills). For both models, a high percentage of people having developed PC or Internet skills does not have a high influence on a pro-environmental behavior. Probably these IT oriented people are so focused on the digital world that they do not find time and interest for the environment. The influence of the percentage of people having less developed PC or internet skills (1-2 PC skills and 1-2 internet skills) on the recycling rate is a slightly higher than in the case of well qualified people, but yet not highly significant. Similar results have been confirmed by researches, which have shown that a higher education has a positive effect on the pro-environmental behavior (Sardianou, Genoudi, 2013) and the lack of education has a negative effect on the recycling rate in an economy (Pelau, Chinie, 2018). This model complements the existing results, by proving that a certain type of skills has a higher influence on the pro-environmental behavior and on the recycling rate.

The limitations of the research refer to the fact that for the statistical indicator E-skills, there is not clearly mentioned what type of PC or internet skills are considered. Therefore, it depends on the respondent's panel, what they have considered as an e-skill. Besides the data for the e-skills indicators are not available for every year considered in the panel. Because of this, it was also not possible to integrate the two types of skills (PC-skills and internet skills) in a combined model.

Taking into consideration the dynamic and rapid development of digital technologies and the growing number of people working with the computer and on the internet, it is important to analyze the influence of the development of these skills on the environment. Some people have the tendency to focus too much on the digital world, so that they forget the real world and the environment. This fact has been also confirmed by our research by showing that people with high e-skills have a smaller influence on the recycling rate. For the future, it is important to increase the awareness of all categories of people and especially to the high qualified PC and internet users, about the importance of pro-environmental behaviour.

\section{REFERENCES}

[1] Boldero, J. (1995), The Prediction of Household Recycling of Newspapers: The Role of Attitudes, Intentions, and Situational Factors; Journal of Applied Social Psychology, 25, 440-462;

[2] Conke, L. (2018), Barriers to Waste Recycling Development: Evidence from Brazil; Resources, Conservation \& Recycling, 134:129-135; 
Daniela Serban, Corina Pelau, Violeta Dinca

[3]Cornell, S.; Berkhout, F. et al. (2013), Opening up Knowledge Systems for Better Responses to Global Environmental Change; Environmental Science \& Policy, 28, 60-70;

[4] Dai, Y. C.; Gordon, M. P. R.; Ye, J. Y.; Xu, D. Y.; Lin, Z. Y.; Robinson, N. K. L., et al. (2015), Why Door Stepping Can Increase Household Waste Recycling; Resources, Conservation and Recycling, 102, 9-19;

[5] Empirica (2009), Monitoring E-Skills Demand and Supply in Europe, available at:

http://projects.mcrit.com/foresightlibrary/attachments/Meskills\%20Scenario\%20an d\%20Foresight\%20report_final.pdf, Published: 8.11.2009, Retrieved: 19.06.2018;

[6] European Commission (2014), E-skills: the international dimension and the impact of globalization-final report, available at:

https://ec.europa.eu/docsroom/documents/6841/-

attachments/1/translations/en/renditions/pdf, published: 23.09.2014, retrieved:

09.06.2018;

[7] European Commission (2017), Review of Waste Policy and Legislation, available at: http://ec.europa.eu/environment/waste/target_review.htm, Published:

1.12.2017, Retrieved: 6.06.2018;

[8] [Data] Eurostat (2018), Average Number of Rooms per Person by Tenure Status and Dwelling Type from 2003 onwards - EU-SILC survey (code:

ilc_lvho03), available at:

http://appsso.eurostat.ec.europa.eu/nui/show.do?dataset=ilc_lvho03\&lang=en, retrieved: 24.05.2018;

[9] [Data] Eurostat (2018), E-skills (code: isoc_bde15csk), available at: http://appsso.eurostat.ec.europa.eu/nui/submitViewTableAction.do, retrieved: 24.05.2018;

[10] [Data] Eurostat (2018), Population by educational attainment level, sex and age (\%) - main indicators (Code: edat_lfse_03), available at:

http://appsso.eurostat.ec.europa.eu/nui/show.do?dataset=edat_lfse_03\&lang=en, retrieved: 24.05.2018;

[11] [Data] Eurostat (2018), Recycling rate of municipal waste (code:

cei_wm011), available at:

http://ec.europa.eu/eurostat/tgm/table.do?tab=table\&init=1\&language=en\&pcode= cei_wm011\&plugin=1, retrieved: 24.05.2018;

[12] Fuchs, C. (2008), The Implications of New Information and

Communication Technologies for Sustainability; Environment, Development and Sustainability, 10 (3), 291-309; 
Panel Data Analysis for Measuring the Impact of E-skills on the Ecological Behavior of Individuals

[13] Gareis, K.; Husing, T.;Birov, S.; Bludova, I.; Schulz, C.; Korte, W.B. (2014), E-skills for Jobs in Europe: Measuring Progress and Moving ahead Final Report, Empirica, Bonn, Germany;

[14] Guerrero, L.A.; Maas, G.; Hogland, W. (2013), Solid Waste Management Challenges for Cities in Developing Countries; Waste Management, 33, 220-232; [15] Izagirre-Olaizola, J.; Fernández-Sainz, A.; Vicente-Molina, M.A. (2014), Internal Determinants of Recycling Behavior by University Students: A CrossCountry Comparative Analysis. International Journal on Consumer Studies, 39, 25-34;

[16] Jesson, J.K.; Pocock, R.; Stone, I. (2014), Barriers to Recycling: A Review of Evidence Since 2008, M-E-L Research/WRAP;

[17] Kinnaman, T.C.; Shinkuma, T.; Yamamoto, M. (2014), The Socially

Optimal Recycling Rate: Evidence from Japan. Journal of Environmental Economics and Management, 68 (1), 54-70;

[18] Klöckner, C.A.; Oppedal, I.O. (2011), General versus Domain Specific Recycling Behavior - Applying a Multilevel Comprehensive Action Determination Model to Recycling in Norwegian Student Homes; Resources Conservation Recycling, 55, 463-471;

[19] McCormack, A. (2010), The E-skills Manifesto; European Schoolnet, Brussels, Belgium;

[20] Miranda Carreno, R. \& Blanco Suarez, A. (2010), Environmental Awareness and Paper Recycling; Cellulose Chemistry and Technology, 44(10), 431-449;

[21] Oztenkin, C.; Teksoz, G.; Pamuk, S.; Sahin, E.; Kilic, D.S. (2017), Gender Perspective on the Factors Predicting Recycling Behavior: Implications from the Theory of Planned Behavior; Waste Management, 62, 290-302;

[22] Park, S. (2018), Factors Influencing the Recycling Rate under the Volumebased Waste Fee System in South Korea; Waste Management, 74, 43-51;

[23] Pelau, C.; Chinie A.C. (2018), Econometric Model for Measuring the Impact of the Education Level of the Population on the Recycling Rate in a Circular Economy; Amfiteatru Economic, 48, 340-355;

[24] Popescu, G.; Boboc, D..; Stoian, M.; Zaharia, A.; Ladaru, G.R. (2017), A Cross-Sectional Study of Sustainability Assessment; Economic Computation and Economic Cybernetics Studies and Research, 51(1), 21-36;

[25] Ramayah, T.; Lee, J.W.C.; Lim, S. (2012), Sustaining the Environment through Recycling: An Empirical Study; Journal of Environmental Management, 102, 141-147; 
Daniela Serban, Corina Pelau, Violeta Dinca

[26] Rhodes, R.E.; Beauchamp, M.R.; Conner, M.; de Bruijn, Gert-Jan; Kaushal, N.; Latimer-Cheung, A. (2015), Prediction of Depot-Based Specialty Recycling Behavior Using an Extended Theory of Planned Behavior; Environment and Behavior, 47, 1001-1023;

[27] Seacat, J.D.; Northrup, D. (2010), An Information-Motivation-Behavioral Skills Assessment of Curbside Recycling Behavior; Journal of Environmental Psychology, 30, 393-401;

[28] Tomlinson, B. (2010), Greening through IT, Information Technology for Environmental Sustainability; MIT Press, Cambridge, MA;

[29] Trudgill, S. (1990), Barriers to a Better Environment: What Stops Us from Solving Environmental Problems; Behaven Press, London;

[30] van Welsum, D. \&Lanvin, B. (2012), E-Leadership Skills - Vision Report, available at: http://eskills-

vision.eu/fileadmin/eSkillsVision/documents/Vision\%20report.pdf, Published: 24.10.2012, Retrieved: 13.06.2018;

[31] Varotto, A.; Spagnolli, A. (2017), Psychological Strategies to Promote Household Recycling. A Systematic Review with Meta-Analysis of Validated Field Interventions; Journal of Environmental Psychology, 51, 168-188;

[32] Zupan, G. (2016), E-skills and Digital Economy, available at: https://www.dlib.si/stream/URN:NBN:SI:DOC-I4QS30XN/d7d71d34-7ae8-4191aa6e-3c45e7a96bc5/PDF, Published: 07.05.2016, Retrieved: 13.06.2018. 